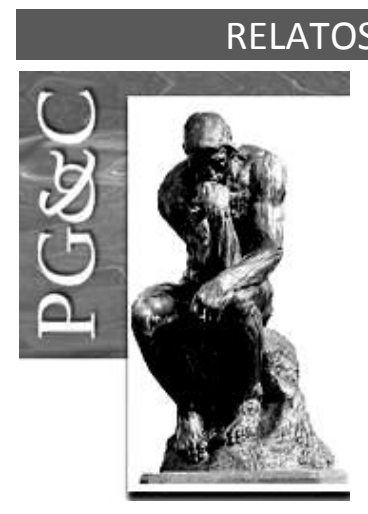

\title{
MANAGING KNOWLEDGE PRODUCTS: A SYSTEM ARCHITECTURE ADDRESSED TO SOFTWARE INDUSTRY
}

\author{
Mariana Santos \\ Mestranda em Gestão do Conhecimento nas Organizações pelo \\ Centro Universitário Cesumar, Brasil. \\ E-mail: mariana santosoliveira@hotmail.com \\ Gisele Caroline Urbano Lourenço \\ Mestranda em Gestão do Conhecimento nas Organizações pelo \\ Centro Universitário Cesumar, Brasil. \\ E-mail: gisele urbano@hotmail.com \\ Lúcio Rogério Lázaro Gomes \\ Tecnólogo em Processamento de Dados pela Universidade Estadual de \\ Maringá, Brasil. \\ E-mail: lucio@dataexport.com.br
}

Flávio Bortolozzi

Doutor em Engenharia de Sistemas Informática pela Universitè de Technologie de Compiègne, França. Professor do Centro Universitário

Cesumar, Maringá, Brasil.

E-mail: flavio.bortolozzi.53@gmail.com

\section{Nelson Tenório}

Doutor em Ciência da Computação pela Pontifícia Universidade Católica do Rio Grande do Sul, Brasil. Professor do Centro Universitário

Cesumar, Maringá, Brasil.

E-mail: nelson.tenorio@unicesumar.com.br

\begin{abstract}
Knowledge is the primary organizational asset since it becomes a source of profit when directly related to the development of the final product. Thus, this is the scenario in which software industry organizations are looking for ways to manage their organizational knowledge, like Knowledge Management (KM), which offers processes for the capture, storage, sharing, and application of organizational knowledge. The individual knowledge within the software industry is explicit through different knowledge products, namely software artifacts. So, investigate means for knowledge products' availability for the whole organization is relevant once it enables them to increase their solving problems capability, keeps their processes updated, and grow into more profitable products. In this sense, a system architecture offers robust and integrated features essential to aid the organizations in knowledge products availability, indexing, and management, besides that can solve the challenge of the knowledge fragmentation. Therefore, this paper presents a system architecture addressed to manage the knowledge products grounded in the KM process to capture, storage, sharing and use organizational knowledge. Such the system architecture is essential to help organizations within the software industry improve their KM on their knowledge. Then, it is exploratory research with mixed methods (qualitative and quantitative) that, as a result, presents a system architecture for the management of the knowledge products of organizations belonging to the software development industry.
\end{abstract}

Keywords: Knowledge Fragmentation. Components. Technologies. Knowledge Management.

Perspectivas em Gestão \& Conhecimento, João Pessoa, v. 8, número especial, p. 151-166, out. 2018. DOI: http://dx.doi.org/10.21714/2236-417X2018v8nep151

http://periodicos.ufpb.br/ojs2/index.php/pgc. ISSN: 2236-417X. Publicação sob Licença (cc) EY-NC-ND 


\title{
GERENCIANDO PRODUTOS DO CONHECIMENTO: UMA ARQUITETURA DE SISTEMAS ENDEREÇADA À INDÚSTRIA DE SOFTWARE
}

\begin{abstract}
Resumo
O principal ativo organizacional é "o conhecimento", já que é uma fonte de lucro quando diretamente relacionado ao desenvolvimento do produto final. Este é o cenário no qual as organizações da indústria de software buscam maneiras de gerenciar seus conhecimentos organizacionais, assim como a Gestão do Conhecimento (GC), que oferece processos para captura, armazenamento, compartilhamento e aplicação do conhecimento organizacional. O conhecimento individual dentro da indústria de software é explicitado através de diferentes produtos de conhecimento, isto é, artefatos de software. Assim, investigar os meios para a disponibilidade dos produtos de conhecimento para toda a organização é relevante, uma vez que permite que eles aumentem sua capacidade de solucionar problemas, mantenham seus processos atualizados e se transformem em produtos mais lucrativos. Nesse sentido, uma arquitetura de sistema oferece recursos robustos e integrados essenciais para auxiliar as organizações na disponibilização, indexação e gerenciamento de produtos de conhecimento, além de solucionar o desafio da fragmentação do conhecimento. Portanto, este artigo apresenta uma arquitetura de sistema voltada ao gerenciamento dos produtos do conhecimento apoiados no processo da GC para capturar, armazenar, compartilhar e utilizar o conhecimento organizacional. Essa arquitetura do sistema é essencial para ajudar as organizações da indústria de software a aprimorar a GC. Em seguida, o artigo apresenta uma pesquisa exploratória com métodos mistos (qualitativos e quantitativos) que, como resultado, apresenta uma arquitetura de sistema para a gestão dos produtos de conhecimento das organizações pertencentes à indústria de desenvolvimento de software.
\end{abstract}

Palavras-chave: Fragmentação do Conhecimento. Componentes. Tecnologias. Gestão do Conhecimento.

\section{INTRODUCTION}

Knowledge has become a critical intangible asset of great value to organizations, especially in the search for competitive advantage. Managing such knowledge is relevant for decision-making within particular software development organizations since its understanding is essential to provide the innovation and sustainability (NATALE; NEVES; CARVALHO, 2016). Knowledge Management (KM) is a cyclical and dynamic process defined by different and interdependent stages and related to the creation, acquisition, dissemination, development, and application of knowledge which generate value to their products and services (LAVERDE; BARAGAÑO; DOMINGUEZ, 2003; TAKEUCHI; SHIBATA, 2006). The Brazilian software industry has been growing and looking for solutions to manage its organizational knowledge (LOURENÇO et al., 2016) effectively. KM comes as a set a of principles, concepts, processes, practices, and tools to support the knowledge application or use (DOROW; CALLE; RADOS, 2015). KM allied with technology provides an efficient and structured environment (MARIANO; CARREIRA, 2010) which improve the organization's competitiveness and sustainability (OLIVEIRA et al., 2016). However, in the software companies, the organizational knowledge tends to get fragmented when is not well managed (TENÓRIO et al., 2017). So, the literature present different strategies to manage well the organizational knowledge based on systems (CHOY et al., 2018; KING; MARKS, 2008), ontologies (BARÃO et al., 2017; ALFREDO SÁNCHEZ et al., 2012), and system architectures (CISLAGHI, 2008; FREITAS JÚNIOR et al. 2017; NARTEH, 2008; OLIVEIRA; PINTO; TENÓRIO, 2017). Considering those different strategies, a system architecture is the most which provide robust means to capture, store, share, and use organizational knowledge (THOMAS; HETTIGE, 2012). Moreover, due to the importance of the knowledge product for the software development (OLIVEIRA; PINTO; TENÓRIO, 2017) there is a lack of proposals specific to manage the knowledge in the knowledge products, i.e. software

Perspectivas em Gestão \& Conhecimento, João Pessoa, v. 8, número especial, p. 151-166, out. 2018. 
artifacts, built by the software industry. In this sense, the research question for this work is: Which sort of components and technologies support a system architecture to manage the knowledge product for the software industry?

Therefore, this paper presents a system architecture called KP-Arch (i.e., Knowledge Product Architecture), which is addressed to manage the knowledge products grounded in the KM process of knowledge capture, storage, sharing and use. The system architecture was built based on previous researches and validated by three experts. For this, the work is organized into five sections. Followed by this introduction, section 2 presents a literature review showing the theoretical basis of the research. Section 3 gives the research method used in this research. Section 4 points out our results and followed by discussions. Finally, section 5 presents our conclusion and the references cited in this work.

\section{LITERATURE REVIEW}

This section introduces KM concepts showing how the software industry handle with its knowledge currently. Following, we present the concepts regarding systems architecture and the different KM cycles available in the literature. Afterward, we present the KM cycle adopted in this paper followed by the concepts regarding knowledge products.

\subsection{Knowledge Management and the Software Industry}

At the end of the 20th century, it was evident that knowledge became the primary factor of production for organizations, is responsible for structural and productive changes (SANTOS et al., 2016). Consequently, there was a significant growth of information by the organizations that, in turn, establish methods to identify, manage, share and maintain the knowledge within their environment (NORTH, 2010).

Laudon (2011) states that if knowledge is not shared, organized and applied, it will have no value to the organization. Thus, the organization that manages its knowledge benefits from it and has higher possibility to innovate products and services, remaining sustainable in the market in which it operates. In this context, knowledge started being managed within organizations so that they could conquer a prominent place in the market, improving their performance, maximizing their business opportunities and minimizing their risks of losing opportunities (SCHIUMA; CARLUCCl; LERRO, 2012). In addition, knowledge management ensures the well-being and long-term viability of organizations (WIIG, 1997). Knowledge is one of the critical resources for organizations in this industry to continue to offer differentiated products and services that can add value to customers and their businesses (GASPAR; DONAIRE, 2016). Therefore, KM should be considered as a facilitator of the transformation of knowledge into assets aimed at the viability of continued and sustainable growth (CARRILLO; ANUMBA, 2005).

The fact is that KM has become relevant within the organizational environment, promoting the creation of a knowledge base together with individual competences, thoughts, innovations, and ideas (DALKIR, 2011). According to Wiig (1997), KM seeks to make organizational actions intelligent, building an organization capable of transforming, organizing, deploying and using knowledge resources, and continuously renewing them. This process remains the same within software development organizations since these organizations have a peculiar characteristic that distinguishes them from other organizations. This means that they perform knowledge-intensive activities, generating high added-value products (BJØRNSON; DINGS $\varnothing Y R, 2008$ ).

In this sense, KM should be supported by a set of practices aimed at the creation, dissemination, and application of knowledge within the organization (KEBEDE, 2010). These

Perspectivas em Gestão \& Conhecimento, João Pessoa, v. 8, número especial, p. 151-166, out. 2018. 
practices should consider both the tacit knowledge, that is, the one related to the experiences and insights of individuals, and the explicit knowledge that, in some way, has been articulated in some record, which can be composed of media, documents, manuals, among others. (TAKEUCHI; NONAKA, 2008).

However, the primary challenge within software development organizations is to use knowledge to address management and other organizational issues. In this sense, KM becomes the organizational learning facilitator, to improve the organization's ability to learn from its environment and to incorporate knowledge into its processes (AURUM; DANESHGAR; WARD, 2008).

Therefore, organizations that recognize knowledge as an essential strategic and productive asset increase their need to create, store, distribute and retain more efficiently the existing knowledge (CARDOSO; MACHADO, 2008). When organizations know how to identify and use knowledge strategically and innovatively, they become able to perform better in their routines, profits, productivity, and sustainability, in addition to becoming competitive in the market in which they operate.

\subsection{Systems Architecture}

Systems architecture, also called as software architecture, is one of the primary enablers regarding providing useful gains in agility and efficiency in the maintenance and evolution of corporate information systems, a preponderant factor for competitive environments (SORDI, 2006). For Richardson et al. (1990), a systems architecture should not be seen as a formal solution to every technological problem, since the goal of architecture is to interrelate data and make hardware, software and communication resources available. Also, according to the authors, an architecture must be able to produce information and support a variety of domains of human activity. For Shaw and Garlan (1996) a systems architecture establishes what a system is in terms of computational components and the relationships between these components. Thus, systems architecture can be considered a set of statements that describes the software components and assigns system functionalities to each of them. Therefore, it represents the technical structure, limitations, and characteristics of the components as well as the interfaces among them (SORDI, 2006), being the 'skeleton' of the system and, therefore, becoming the highest-level plan of the construction of each new system (KRAFZIG, BANKE; SLAMA, 2004).

In order to serve organizations, the systems architecture must be: simple (so that all its actors can understand and use it); flexible (so that it can accommodate in time the dynamic changes required by the business environment); reuse-generating (mainly software blocks); and able to unlink business functionalities from the technologies used for their execution (SORDI, 2006). The primary use of systems architecture can have an impact on at least five aspects of its development. For Garlan and Perry (1995), these aspects are:

- Understanding: to understand large systems at a level of abstraction in which design can be understood by the those involved;

- Reuse: to know how to reuse components that have been utilized in other architectures, at various levels;

- $\quad$ Evolution: to expose the dimensions to which a system should evolve to understand the changes into it is better. Also, estimate the costs of these changes;

- $\quad$ Analysis: To provide new analysis opportunities, including a high level of abstraction and check the consistency of the system as a whole;

Perspectivas em Gestão \& Conhecimento, João Pessoa, v. 8, número especial, p. 151-166, out. 2018. 
- Management: To improve the feasibility and specification of system requirements through the implementation of an architecture.

In addition, a systems architecture is essential to reduce app development costs and increase the potential of the different connected components of products (MEDVIDOVIC; TAYLOR; SOCIETY, 2000). Thus, an architecture model for knowledge products aligned with KM processes such as capture, storage, sharing and use, defines the aspects of an innovative and sustainable organizational vision. Thus, knowing how to capture, manage, maintain and share knowledge products that exist within the organization is of great importance, since organizations gain agility to solve problems that may occur, in addition to becoming more competitive and profitable, keeping their processes always renewed and increasing competitiveness and sustainability in the current market.

\subsection{Knowledge Management Cycles}

KM cycles are processes formed by some procedures that seek to capture, store, share and use knowledge efficiently. The literature presents different KM cycles, as shown in Table 1.

Table 1 - Different KM cycles present in the literature.

\begin{tabular}{l|l}
\hline Authors & Knowledge Processes \\
\hline Wiig (1993) & Build, retain, distribute, apply \\
\hline Meyer; Zack (1996) & $\begin{array}{l}\text { Acquire, refine, store and retrieve, distribute, } \\
\text { present }\end{array}$ \\
\hline Davenport; Prusak (1998) & Generate, encode, transfer \\
\hline Alavi; Leidner (2001) & Create, store and retrieve, transfer, apply \\
\hline Bukowitz; Williams (2002) & $\begin{array}{l}\text { Acquire, use, learn, contribute, access, build and } \\
\text { support, discard }\end{array}$ \\
\hline McElroy (2003) & Produce, integrate, feedback \\
\hline CEN (2004) & Identify, create, store, share and apply \\
\hline Narteh (2008) & Convert, route, disseminate, apply \\
\hline Liyanage et al. (2009) & Identify, acquire, transform, associate and apply \\
\hline APO (2010) & Identify, create, store and apply \\
\hline Tenório et al. (2017) & $\begin{array}{l}\text { Creation/capture, sharing/dissemination, } \\
\text { acquisition and use }\end{array}$ \\
\hline
\end{tabular}

Source: The Authors, 2018

For this work, we used the cycle shown in Figure 1 because they are the fundamental knowledge management processes that a software development organization can use when dealing with knowledge products. The capture process involves the acquisition of knowledge, which can be acquired through external and internal data of the organization. That is when individual knowledge becomes organizational knowledge for the organization's employees. For Dorow et al. (2015), capture relates to activities in which the organization identifies knowledge gaps, and creates or incorporates new knowledge from those gaps, that can be improved through an existing knowledge base. The storage process has the function of ensuring that the knowledge that has already been captured in some way is stored in some repository so that it is safe and accessible to the employees of an organization. The sharing knowledge process is understood as the distribution of knowledge among the employees of an organization. After being stored, this knowledge must be distributed so that people can make use of it. This process can be defined as activities through which knowledge is transferred to the right place, at the right time and with the right quality, maintaining its adequate context and, almost always, using information technology support (CEN, 2004). According to Tenório et al. (2017),

Perspectivas em Gestão \& Conhecimento, João Pessoa, v. 8, número especial, p. 151-166, out. 2018. 
the use process of knowledge refers to the flow of the knowledge captured or created within the organization to be used by people in diverse situations, such as decision-making.

Figure 1 - KM cycle on which the proposed architecture is based.

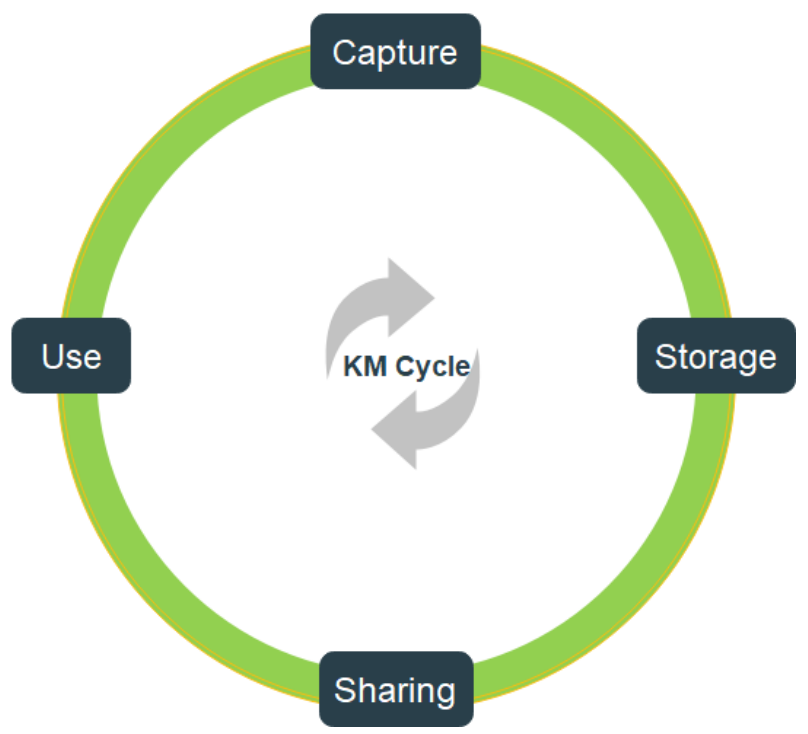

Source: The authors (2018)

Once knowledge is created, stored, and shared, it is available to be used by individuals. This use process helps the application of knowledge in various situations of the organization's routine.

\subsection{Knowledge Products}

Knowledge products can be useful to the organization for acquiring knowledge collaboratively and cooperatively, being able to capture, store, share and use such knowledge products. People are essential in a knowledge creation process, within an organization, but it is necessary to understand that they are not mere processors of information, but must be considered creators of knowledge (MAGALHÃES, 2005). This way, knowledge products are generated through the knowledge of the individuals inside the organization. Such knowledge can be disseminated based on knowledge products such as documents, software artifacts, videos, podcasts, articles, among others (SCALABRINI et al., 2016). According to Pressman (2010), a software artifact is any device that supports the understanding of everyone involved in the software development process. Dalkir (2005) states that a shared repository within an organization assists in the storage and sharing of knowledge products and communication among an organization's employees.

Thus, software development organizations regularly generate knowledge products through the software artifacts created during the development or maintenance phase of a product. A software artifact corresponds to documentation, such as a template, or another object of value created during development (AZEVEDO JUNIOR; CAMPOS, 2008), e.g., diagram of use cases, class diagram, activity diagram and requirements documentation, among others. Thus, documents generated within a software development organization can be considered products of knowledge. When organizations have methods for capturing, storing, sharing and using knowledge products, they can increase their productivity, sustainability, and

Perspectivas em Gestão \& Conhecimento, João Pessoa, v. 8, número especial, p. 151-166, out. 2018. 
competitiveness in today's market by streamlining their decision-making based on such products.

\section{METHOD}

To present a system architecture addressed to manage the knowledge products within the software industry, we carried out in-depth bibliographical research which gave us insights regarding the architecture. In addition, we validated the architecture with three different experts. The bibliographic research was carried out regarding KM cycles and using the following scientific databases: Portal of Periodicals of CAPES, Science Direct, Web of Science and Google Scholar. The keywords used were in Portuguese 'arquitetura de sistemas' and 'gestão do conhecimento' and 'produtos do conhecimento'; and in English 'knowledge management' and 'system architecture' and 'knowledge product'. During our insights, we chose the components and technologies of the system architecture carefully to support knowledge products and software development organizations.

Moreover, we considered the structural and technological aspects proposed by Oliveira et al. (2017) and Tenório et al. (2017). Finally, we validated our proposal by interviewing two KM expert and one software engineering during August of 2018 to identify the strengths and weaknesses of our proposal. In addition, we used the content analysis, proposed by Bardin (2010), in which a set of systematic techniques and procedures is proposed so to that the inference of relational knowledge can occur. Finally, the empirical material of the interviews was analyzed as suggests Creswell (2013, p. 245).

\section{RESULTS AND DISCUSSION}

In this section we present our proposal for a knowledge products system architecture addressed to software development organizations.

\subsection{System Architecture General Technologies}

Several studies present different types of architecture involving different technologies to support KM practices and processes. Oliveira, Pinto, and Tenório (2017) present the comparison of the technologies that can be used by a systems architecture that creates, stores, shares and uses knowledge products aimed at software development organizations. Such technologies are presented in Table 2.

Table 2 - Technologies focused on the systems architecture aimed at the KM cycle.

\begin{tabular}{l|l|l|l}
\hline \multirow{2}{*}{ Proposal } & KM Processes & Application and Use \\
\cline { 2 - 4 } & Capture & Storage and Coding & $\begin{array}{l}\text { Organizational } \\
\text { memory }\end{array}$ \\
\hline Miban (2002) & Data Mining & Data Warehouse & Services \\
\hline Cislaghi (2008) & Data mining & $\begin{array}{l}\text { Data Warehouse; Data } \\
\text { Mart }\end{array}$ & $\begin{array}{l}\text { Web-based access } \\
\text { system }\end{array}$ \\
\hline Biz (2009) & GED; e-mail & Database & A knowledge portal \\
\hline Freitas Júnior et al. (2017) & External Applications & Repositories & \\
\hline
\end{tabular}

Source: Adapted from Oliveira et al. (2017)

Martins, Omar, and Diban (2002) present a system architecture for KM that has the following components: Data Mining, Data Warehouse, and Organizational Memory. According

Perspectivas em Gestão \& Conhecimento, João Pessoa, v. 8, número especial, p. 151-166, out. 2018. 
to the authors, such components make it possible to obtain reliable information for decision making through the management of organizational knowledge. The Data Mining component is responsible for capturing and filtering organizational information. The Data Warehouse component is responsible for storing the information in a large enterprise database, which is composed of useful knowledge that is going to be used by the organization in the future. Finally, the Organizational Memory, which is part of the Data Warehouse environment, has the function of facilitating the use of knowledge through its dissemination. Although the authors' architecture is quite robust, there are few details regarding the technology to be used, which can be a barrier to its implementation (e.g., data mining algorithms and the Data Warehouse model could be presented in detail as an implementation guide).

The architecture presented by Cislaghi (2008) consists of three components. The first component is Data Mining to generate useful knowledge for the organizations. The second component is a Data Warehouse, which is a database addressed to store and structure the information in a suitable format for it all to be queried. Finally, the third component consists of services such as video conferencing, forum, and search, which enable the use of the knowledge generated by the organization. Biz (2009) offers two components to data collection in which one is responsible of extracting data from electronic documents and storing it in a local database, and another one responsible for extracting data of sending and receiving messages. Although both components provide access to organizational knowledge, the solution is limited by data collection of electronic documents and e-mail, since applications such as Skype, WhatsApp, Slack, among others, also provide knowledge flow. Finally, Freitas Júnior et al. (2017) present a system that uses as components external applications, data repository and a knowledge portal. It is possible to perform the creation and the capture of the knowledge through the applications. The data repository is responsible for storing the data that has been captured in the previous step.

Finally, the knowledge portal is used to apply the knowledge within the organization. However, the authors' architecture does not discuss or present the technological aspects which are essential to system architecture, or software. This makes it difficult to implement the architecture in technological terms. It is also observed that none of these architectures is specific to software development organizations and based on elements designed to deal with knowledge products.

\subsection{KP-ARCH - The Knowledge Products Architecture}

Given the KM systems architectures presented in the previous section, even though none of which addresses an architecture focused on the knowledge products of organizations belonging to the software industry, which is essential for capture, store, share, and use knowledge within the organization. In this sense, Table 3 presents the components and technologies required to the knowledge products system architecture, so-called KP-Arch. The process of capturing knowledge products within a software development organization can be accomplished in KP-Arch through the integration with software development support tools. In this process, some kinds of tools can be highlighted, such as project management tools, bug tracking system and version control system. In this sense, tools such as Redmine, MS-Project, Subversion, among others, which were identified by Tenório et al. (2017) in order to support software development processes. Those tools store product knowledge through a variety of products that have been created, e.g., software modeling, requirements, and manuals. According to Falbo and Travassos (1996), this environment seeks to combine techniques, methods, and tools to support the software engineer in the construction of software products, covering all activities in software production, such as planning, development and quality control. To integrate the systems with the components used in the architecture can be

Perspectivas em Gestão \& Conhecimento, João Pessoa, v. 8, número especial, p. 151-166, out. 2018. 
adopted standards such as XML, CSV, JSON, among others. With those components, the KPArch is able the knowledge products capture can be more dynamic for software development organization.

The process of storing and sharing knowledge products in the KP-Arch can be accomplished through the text mining component, which is responsible for finding relevant terms in the stored knowledge products' text documents. It is relevant to establish the standards and relationships between the documents, based on the frequency and thematic of the terms found (SERAPIÃO et al., 2010). Observing the proposals of the Oliveira et al. (2017), Pinto et al. (2017), and Tenório et al. (2017), we find out that data mining component is essential for KM systems. Therefore, the text mining component is relevant for KP-Arch since it classifies text-based knowledge products which are very common in software development organizations, e.g., system requirements and user manuals.

Table 3 - Technologies and components of the proposed architecture.

\begin{tabular}{|c|c|c|}
\hline KM Processes & Technologies & Architecture Components \\
\hline Capture & $\begin{array}{l}\text { XML, CSV and/or JSON integration } \\
\text { standard }\end{array}$ & $\begin{array}{l}\text { Integration between following } \\
\text { software development tools: } \\
\text { project management, version } \\
\text { control, and bug tracking systems }\end{array}$ \\
\hline Storage & \multirow[t]{2}{*}{$\begin{array}{l}\text { Data warehouse, relational } \\
\text { database, cloud drives }\end{array}$} & $\begin{array}{l}\text { Text mining, knowledge maps, } \\
\text { metrics and measures collector }\end{array}$ \\
\hline Sharing & & $\begin{array}{l}\text { Corporate portals, communities of } \\
\text { practice }\end{array}$ \\
\hline Use & $\begin{array}{l}\text { Intuitive and available interfaces to } \\
\text { the web and mobile technologies }\end{array}$ & $\begin{array}{l}\text { Search engines and indicator } \\
\text { monitoring }\end{array}$ \\
\hline
\end{tabular}

Source: The authors (2018)

The knowledge mapping component aims to locate essential knowledge regarding knowledge products to later publish and disseminate for the users, where they are found. According to Batista (2004), knowledge mapping makes it possible to record all organizational knowledge in documents because, whether a collaborator is absent from a specific organization, the knowledge he has acquired can be recorded in documents through which the other employers can access it. However, in the literature, we observed that none of the architectures use this component, which is essential for the KP-Arch since it supports the storage and sharing processes of knowledge products.

The metric collector component intents to collect metrics and measures that can then monitor knowledge products through indicators. That way, team leaders, managers, and directors can access information such as the most commonly accessed knowledge products, how many knowledge products are created in each period, what communities of practice the software development team are part of, and so on. This component assists the organization's tactical and strategic level in decision-making, for example, which is the most developed 'knowledge' within the teams, which is the least developed one, which area needs training, among others. So, this component enables KP-Arch measure the organizational knowledge allowing, for instance, the implementation of KM diagnoses.

Different technologies are required to support KP-Arch components. Thus, our architecture suggests three sorts of storage means such as a data warehouse, a relational database, and cloud drives. According to Batista (2004), the data warehouse can be defined as the process of tracking data arranged in relational databases, allowing versatility in the manipulation of large amounts of data. The relational database is designed to create relationships between two or more tables with different knowledge products. The storage of

Perspectivas em Gestão \& Conhecimento, João Pessoa, v. 8, número especial, p. 151-166, out. 2018. 
knowledge products can be done using cloud drives, which can be Google Drive, Dropbox, OneDrive, which keep these knowledge products safer and have greater mobility for accessing products. In this sense, two of those KM architectures presented in Table 2 are based on data warehouse technology, and one of them is based on database technology. Then, those technologies are essential to KP-Arch supports knowledge product storage process.

In the KP-Arch we include the corporate portal component which addressed to integrate several information systems for sharing of the knowledge products. This is important for knowledge dissemination across the organization's employees and enabling the exchange of experiences among them (GORDON, 2002). When analyzing the architectures presented in Table 2, we figured out that none of them suggest a corporate portal. However, the focus of those architectures was not on the software development organizations and the knowledge products, but on general KM architectures instead. Therefore, the corporate portal is relevant for KP-Arch because it allows the reduction of costs and the improvement in the relationship between employees and clients.

The community of practice component is responsible for having an organization's employees come together to improve what they do, or to exchange experiences with one another. For Batista (2004), the community of practice is characterized by interest meetings, seeking transfer of best practices, access to specialists and, also, the utilization of models, knowledge, and lessons learned. That way, the team, project manager, architects, among others, can learn more from exchanges of experiences and lessons assimilated, in addition to sharing knowledge products. So, the KP-Arch has a community of practice component in order to improve both organizational learning and knowledge sharing.

We suggest search engines in the KP-Arch to standardize the users seek for a knowledge product stored within a knowledge database. Tasca et al. (2010) highlight the importance of a minimum standardization of the search engines on databases or the internet has given several possibilities of the search. None of the architectures presented in the literature (Table 2) suggest search engines find and use knowledge products. Thus, search engines are relevant to KP-Arch once the search for knowledge products becomes faster and more efficient for users, after its standardization.

Finally, the KP-Arch presents a monitoring component of knowledge product indicators, which has the role of monitoring knowledge products. Thus, software development organizations can achieve higher productivity and competitive advantage in the current market because the use of IT associated with KM, creates a process which can create, store, share and use knowledge products. In addition, the architecture needs an intuitive interface for the user. Braga (2004) defines an interface as the point at which a user, task, and tool communicate, interact and become a single element. With an intuitive and user-friendly interface, users can do their work more quickly and efficiently to search, use, share, capture and monitor knowledge products. Figure 2 presents the KP-Arch and its respective components and technologies.

We validated the KP-Arch with three experts, two of them KM practitioners and another one software engineering. The KM experts observed that the architecture did not preview the knowledge creation process in which is essential for the organizations. However, we explained to them that the knowledge creation process is the result of the whole architecture cycle since the knowledge is created before the combination presented by the $\mathrm{SECl}$ model of Nonaka e Takeuchi. Thus, the knowledge creation occurs by mean of conversation, documents (i.e., knowledge products), meetings, computer networks (e.g., internet and intranet). All of those means can provide to individuals with new knowledge and insights (TAKEUCHI; SHIBATA, 2006). A KM expert also observed that the architecture could facilitate the knowledge flow once it offers a structure to the individuals access the organizational knowledge. In this sense, Stewart (1998) presents the organizational needs to

Perspectivas em Gestão \& Conhecimento, João Pessoa, v. 8, número especial, p. 151-166, out. 2018. 
build structures that make available the knowledge for the whole organization getting a strategic resource. Finally, the software engineer observed that the components and technologies used in the architecture are well aligned with the current technological reality of the software industry. In this way, de Martins, Omar and Diban (2002), Cislaghi (2008), Biz (2009), Freitas Júnior et al. (2017) also use some of those components and technologies.

Figure 2 - KP-Arch: The knowledge product architecture for software industry.

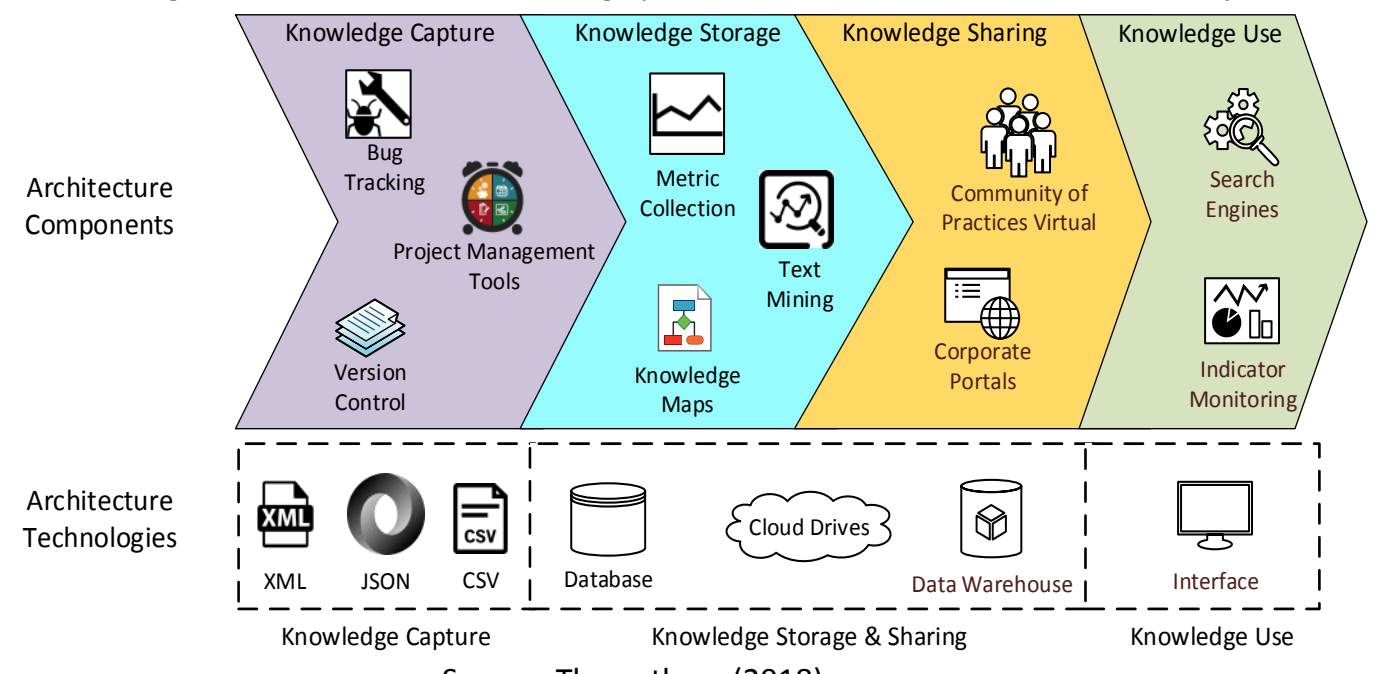

Source: The authors (2018)

Therefore, KP-Arch encompasses components that aim to satisfy the processes of a KM cycle geared to software development organizations. With this architecture, knowledge products can be created, stored, shared, and used within the organization, making the organization more productive, profitable, and useful in its processes.

\section{CONCLUSIONS}

This paper presented a system architecture so-called KP-Arch for the creation, storage, sharing, and use of knowledge products addressed to the software development organizations based on literature review and exploratory research. Therefore, KP-Arch offers a set of components for the integration of tools to support software development, text mining, knowledge maps, metrics and measures collector, corporate portals, communities of practice, search engines and indicator monitoring. In order to support such architectural components of $\mathrm{KP}$-Arch, we suggested different technologies such as XML, CSV and JSON, data warehouse, relational database, cloud storage and intuitive web or mobile interfaces. Moreover, KP-Arch was validated by two KM experts and one software engineering. Although the KM experts observe that KP-Arch does not explicit the knowledge creation process, the entire architecture converges to knowledge creation. In addition, KP-Arch is able to improve the knowledge flow within the software development organizations and is built with current components and technologies used by the software industry. In this way, our proposal is essential to enable decision-making of the software engineers, as well provide a structure that stimulates the knowledge reuse and avoid the knowledge fragmentation. Manage knowledge products is fundamental to the software industry since individual knowledge becomes collective and can be shared with all people, applied in the whole organization, and enhances its processes and products. Therefore, this paper breaks new ground offering the researchers an interesting material to implement the architecture here presented to support knowledge products, avoid

Perspectivas em Gestão \& Conhecimento, João Pessoa, v. 8, número especial, p. 151-166, out. 2018. 
knowledge fragmentation, and collect knowledge metrics useful in decision-making within the software industry.

\section{REFERENCES}

ALAVI, M.; LEIDNER, D.E. Knowledge Management and Knowledge Management Systems: Conceptual Foundations and Research Issues. MIS Quarterly, v. 25, n. 1, p. 107-136, 2001.

ALFREDO SÁNCHEZ, J.; MEDINA, M. A.; STAROSTENKO, O.; BENITEZ, A.; DOMÍNGUEZ, E. L. Organizing open archives via lightweight ontologies to facilitate the use of heterogeneous collections. Aslib Proceedings: New Information Perspectives, v. 64, n. 1, p. 46-66, 2012.

APO. Knowledge Management Tools and Techniques Manual. Asian Productivity Organization, 2010. Retrieved from: http://www.apotokyo.org/publications/ebooks/knowledge-management-tools-and-techniques-manual-pdf$2 \mathrm{mb} /$. Accessed in: July $28^{\text {th }}, 2018$.

AURUM, A.; DANESHGAR, F.; WARD, J. Investigating Knowledge Management practices in software development organisations - An Australian experience. Information and Software Technology, v. 50, n. 6, p. 511-533, 2008.

AZEVEDO JUNIOR, D. P. DE; CAMPOS, R. DE. Definição de requisitos de software baseada numa arquitetura de modelagem de negócios. Produção, v. 18, n. 1, p. 26-46, 2008.

BARÃO, A.; DE VASCONCELOS, J. B.; ROCHA, Á.; PEREIRA, R. A knowledge management approach to capture organizational learning networks. International Journal of Information Management, v. 37, n. 6, p. 735-740, 2017.

BARDIN, L. Análise de conteúdo. 4. ed. Lisboa: Edições70, 2010.

BATISTA, F. F. Governo que aprende: gestão do conhecimento em organizações do Executivo Federal, $2004 . \quad$ Retrieved from: http://www.ipea.gov.br/portal/index.php?option=com content\&view=article\&id=4602. Accessed in: July $26^{\text {th }}, 2018$.

BIZ, A. A. Uma avaliação dos portais turísticos governamentais quanto ao suporte à gestão do conhecimento. 2009. 242 f. Tese (Doutorado em Engenharia e Gestão do Conhecimento) Universidade Federal de Santa Catarina. Florianópolis, 2009.

BJØRNSON, F. O.; DINGS ØYR, T. Knowledge management in software engineering: A systematic review of studied concepts, findings and research methods used. Information and Software Technology, v. 50, n. 11, p. 1055-1068, 2008.

BRAGA, A. S. Design de interface: as origens do design e sua influência na produção da hipermídia. 2004. 135 f. Dissertação (Mestrado em Comunicação e Semiótica) - Pontifícia Universidade Católica de São Paulo, São Paulo, 2004.

Perspectivas em Gestão \& Conhecimento, João Pessoa, v. 8, número especial, p. 151-166, out. 2018. 
BUKOWITZ, W.R.; WILLIAMS, R.L. Manual de Gestão do Conhecimento. Tradução Carlos Alberto Silveira Netto Soares. Porto Alegre: Bookman, 2002.

CARDOSO, O; MACHADO, R. Gestão do conhecimento usando data mining: estudo de caso na Universidade Federal de Lavras. Revista de Administração Pública, v. 42, n. 3, p. 495-528, 2008.

CARRILLO, P. M.; ANUMBA, C. J. Knowledge management in construction. London: Oxford, 2005.

CEN. European Guide to Good Practice in Knowledge Management. Management Science2, v. 50, n. 3, p. 352-364, 2004.

CHOY, K. L. T.; SIU, K. Y. P.; HO, T. S. G.; WU, C. H.; LAM, H. Y.; TANG, V.; TSANG, Y. P. An intelligent case-based knowledge management system for quality improvement in nursing homes. VINE Journal of Information and Knowledge Management Systems, v. 48, n. 1, p. 103-121, 2018.

CISLAGHI, R. Um modelo de sistema de gestão do conhecimento em um framework para a promoção da permanência discente no ensino de graduação. 273 f. Tese (Engenharia e Gestão do Conhecimento) - Universidade Federal de Santa Catarina. Santa Catarina, 2008.

CRESWELL, J. W. Research design: qualitative, quantitative, and mixed methods approaches. Thousand Oaks: Sage publications, 2013.

DALKIR, K. Knowledge management in theory and practice. 2.ed. England: The MIT Press, 2011.

Knowledge Management in Theory and Practice. Oxford: Routledge, 2005.

DAVENPORT, T. H.; PRUSAK, L. Working knowledge: how organizations manage what they know. Boston: Harvard Business School Press, 1998.

DOROW, P. F.; CALLE, G. A. D.; RADOS, G. J. V. Ciclo de conhecimento como gerador de valor: Uma proposta integradora. Espacios. Vol. 36, n. 12, p. 12, 2015.

FALBO, R. A.; TRAVASSOS, G. H. A integração de conhecimento em um ambiente de desenvolvimento de software. In: CONGRESO ARGENTINO DE CIENCIAS DE LA COMPUTACIÓN: RED DE UNIVERSIDADES CON CARRERAS EN INFORMÁTICA, 2., 1996, San Luis. Anais...San Luis, 1996.

FREITAS JÚNIOR, O. de G.; CARVALHO, V. D. H.; BARROS, P. A. M.; BRAGA, M. de M. Uma arquitetura para sistemas de gestão do conhecimento orientada a grupos de pesquisa. Perspectivas em Gestão \& Conhecimento, v. 7, Número Especial, p. 126-144, 2017.

GARLAN, D.; PERRY, D. Introduction to the Special Issue on Software Architecture. IEEE Transactions on Software Engineering, v.21, n. 4, p.269-274, 1995.

GASPAR, M. A.; SANTOS, S. A. DOS; DONAIRE, D.; KUNIYOSHI, M. S.; PREARO, L. C. Gestão do Conhecimento em empresas atuantes na indústria de software no Brasil: um estudo das

Perspectivas em Gestão \& Conhecimento, João Pessoa, v. 8, número especial, p. 151-166, out. 2018. 
práticas e ferramentas utilizadas. Informação e Sociedade, v. 26, n. 1, p. 151-166, 2016.

GORDON, C. Portais corporativos: a revolução na Gestão do Conhecimento. São Paulo: Negócio Editora, 2002.

KEBEDE, G. Knowledge management: an information science perspective. International Journal of Information Management, v. 30, n. 5, p. 416-424, 2010.

KING, W. R.; MARKS, P. V. Motivating knowledge sharing through a knowledge management system. Omega, v. 36, n. 1, p. 131-146, 2008.

KRAFZIG, D.; BANKE, K.; SLAMA, D. Enterprise SOA: Service-Oriented Architecture Best Practices. Indianapolis: Prentice Hall, 2004.

LAUDON, K.; LAUDON, J. Sistemas de Informação Gerenciais. São Paulo: Pearson Prentice Hall, 2011.

LAVERDE, ORTIZ, ADRIANA, M.; BARAGAÑO, A. F.; SARRIEGUI DOMINGUEZ, J. M. Knowledge Processes: On Overview of the Principal Models. 3rd European Knowledge Management Summer School. Anais...San Sebastian: 2003.

LIYANAGE, C.; ELHAG, T.; BALLAL, T., LI, Q.; Knowledge communication and translation-a knowledge transfer model. Journal of Knowledge Management, v. 13, n. 3, p. 118-131, 2009.

LOURENÇO, G. C. U.; OLIVEIRA, M. S.; PINTO, D.; VIDOTTI, A. F.; TENÓRIO JR., N. Gestão do Conhecimento na Indústria de Software: Um Instrumento para o Levantamento de Requisitos de Ferramentas. In: VIII Mostra Interna de Trabalhos de Iniciação Científica e I Mostra Interna de Iniciação em Desenvolvimento Tecnológico e Inovação 25 a 28 de outubro de 2016. Anais... Maringá, 2016.

MAGALHÃES, R. Fundamentos da Gestão do Conhecimento Organizacional. Lisboa: Silabo, 2005.

MARIANO, A. F.; CARREIRA, M. L. A relação da Tecnologia da Informação com a Gestão do Conhecimento: Definindo os papeis para uma gestão estratégica. Revista de Ciências Gerenciais, v. 14, n. 20, 2015.

MARTINS, J. G.; OMAR, D; DIBAN, N. Uma arquitetura para sistemas de gestão do conhecimento aplicados no ambiente organizacional. In: XXII Encontro Nacional de Engenharia de Produção. 2002, Curitiba. Anais... Curitiba, 2002.

McELROY, M. The new knowledge management: complexity, learning and sustainable innovation. Boston: Butterworth-Heinemann, 2003.

MEDVIDOVIC, N.; TAYLOR, R. N. A classification and comparison framework for software architecture description languages. IEEE Software Engineering, v. 26, n. 1, p. 70-93, 2000.

MEYER, M. H.; ZACK, M. H. The design and development of information products. Sloan Management Review, v. 37, n. 3, p. 43-59, 1996.

Perspectivas em Gestão \& Conhecimento, João Pessoa, v. 8, número especial, p. 151-166, out. 2018. 
NARTEH, B. Knowledge transfer in developed-developing country interfirm collaborations: a conceptual framework. Journal of Knowledge Management, v. 12, n. 1, p. 78-91, 2008.

NATALE, C. H. C.; NEVES, J. T. R.; CARVALHO, R. B. Maturidade em gestão do conhecimento: análise das percepções dos gestores de uma grande empresa de construção civil. Informação \& Informação, v. 21, n. 1, p. 375-406, 2016.

NORTH, K. Gestão do conhecimento: Um guia prático rumo à empresa inteligente. Rio de Janeiro: Qualitymark, 2010.

OLIVEIRA, M. S.; LOURENÇO, G. C. U.; PINTO, D.; VIDOTTI, A. F.; TENÓRIO JR., N. Gestão do Conhecimento: a Importância de um Ambiente Tecnológico. In: I Congresso Internacional de Ciência Tecnologia e Inovação, 2016, Umuarama. Anais... Umuarama, UNIPAR, 2016.

OLIVEIRA, M. S.; PINTO, D.; TENÓRIO JR., N. System Architecture for Knowledge Management: A Comparative Study of Technologies Applied. In: ENCONTRO INTERNACIONAL DE PRODUÇÃO CIENTíFICA, 10., 2017. Maringá. Anais...Maringá, 2017.

PRESSMAN, R. Software engineering: a professional approach. New York: McGraw-Hill, 2010.

RICHARDSON, G.; JACKSON, B.M. \& DICKSON, G. W. A. Principles-Based Enterprise Architecture: Lessons from Texaco and Star Enterprise. MIS/Quartely, vol.14, n.4, pp. 385-403, 1990.

SANTOS, G. S.; VIEIRA, A. C. P.; PIERI, R.; GUIMARÃES, M. L. F.; FABRIS, T. R.; MADEIRA, V. Análise das atividades de gestão do conhecimento entre extensionistas e empresas incubadas: estudo de caso da incubadora da UNESC. Revista de Extensão, v. 1, n. 1, p. 90-107, 2016.

SCALABRINI, L.; PINTO, D.; VIDOTTI, A. F.; TENÓRIO, N. Um Instrumento para a Validação de Indicadores de Criação do Conhecimento na Indústria de Software. In: VIII Mostra Interna de Trabalhos de Iniciação Científica e I Mostra Interna de Iniciação em Desenvolvimento Tecnológico e Inovação 25 a 28 de outubro de 2016, 2016, Maringá. Anais Eletrônico VIII Mostra Interna de Trabalhos de Iniciação Científica UNICESUMAR. Anais... Maringá: UniCesumar, 2016.

SCHIUMA, G.; CARLUCCI, D.; LERRO, A. Managing knowledge processes for value creation. Vine, v. 42, n. 1, p. 4-14, 2012.

SERAPIÃO, P. R. B.; SUZUKI, K. M. F.; MARQUES, P. M. A. Uso de mineração de texto como ferramenta de avaliação da qualidade informacional em laudos eletrônicos de mamografia. Radiologia Brasileira, v.43, n.2, p.103-107, 2010.

SHAW, M.; GARLAN, D. Software architecture. Englewood Cliffs: Prentice Hall, 1996.

SORDI, J. O.; MARINHO, B. L.; NAGY, M. Benefícios da arquitetura de software orientada a serviços para as empresas: análise da experiência do ABN AMRO Brasil. Revista de Gestão da Tecnologia e Sistemas de Informação, v. 3, n. 1, p. 19-34, 2006.

Perspectivas em Gestão \& Conhecimento, João Pessoa, v. 8, número especial, p. 151-166, out. 2018. 
STEWART, A. T. Capital intelectual: A nova vantagem competitiva das empresas. Rio de Janeiro: Campus, 1998.

TAKEUCHI, H.; NONAKA, I. Gestão do conhecimento. Porto Alegre: Bookman, 2008.

TAKEUCHI, H.; SHIBATA, T. Japan, Moving Toward a More Advanced Knowledge Economy: Advanced Knowledge-Creating Companies. Washington: World Bank Institute, 2006.

TASCA, J. E.; ENSSLIN, L.; ENSSLIN, S. R.; ALVES, M. B. M. An approach for selecting a theoretical framework for the evaluation of training programs. Journal of European Industrial Training, v. 34, n. 7, p. 631- 655, 2010.

TENÓRIO, N.; PINTO, D.; VIDOTTI, A. F.; OLIVEIRA, M. S.; LOURENÇO, G. C. U.; BORTOLOZZI, F. Tool Based on Knowledge Management Process: An Interview Protocol to Gather Functional Requirements from Software Industry Experts. MATTER: International Journal of Science and Technology, v. 3, n.1, p. 45-54, 2017.

THOMAS, V.; HETTIGE, H. Knowledge Products and Services: Building a Stronger Knowledge Institution. Mandaluyong City: Independent Evaluation Division, 2012.

WIIG, K. M. Knowledge management: an introduction and perspective. Journal of Knowledge Management, v. 1, n. 1, p. 6-14, 1997.

. Knowledge management foundations. Arlington: Schema Press, 1993.

Artigo recebido em 15/10/2018 e aceito para publicação em 29/10/2018

Perspectivas em Gestão \& Conhecimento, João Pessoa, v. 8, número especial, p. 151-166, out. 2018. 